\title{
PENGEMBANGAN MODEL PEMBELAJARAN KOOPERATIF MENGGUNAKAN PENDEKATAN REALISTIK PADA MATA KULIAH STATISTIKA MATEMATIKA I
}

\author{
Sutrisni Andayani' ${ }^{1)}$, Jazim ${ }^{2)}$ \\ ${ }^{1), 2)}$ Pendidikan Matematika FKIP Universitas Muhammadiyah Metro \\ Email: trisnimath.andy@gmail.com ${ }^{1)}$,jazim_ahmad@yahoo.com ${ }^{2)}$
}

\begin{abstract}
The purpose of this research is developing the cooperative model by using the realistic approach in Mathematic Statistics I. As the form of development and research, collecting data done through observation method, questionnaire, interviewing, and a test. The step of this research are introduction study, plan, develop and evaluation. Based on the introduction study, was developed of cooperative instructional and realistic approach instructional. Syntax in cooperative instructional model done by realistic approach is running well and there are increasing of activity, response and student's learning achievement, and difference of probability explanation using realistic approach. Syntax instructional of the model are 1) material explanation 2) group discussion by using context, model, alternative in problem-solving and finally concluding of all, 3) the group member is given the quiz individually, and 4) the score and reward are given to the group.
\end{abstract}

Keywords: cooperative instructional model, mathematic statistics I, realistic approach

\section{PENDAHULUAN}

Mata kuliah Statistika Matematika I sebagai mata kuliah wajib yang harus dipelajari oleh mahasiswa pada program studi Pendidikan Matematika di Universitas Muhammadiyah Metro. Pada mata kuliah ini masih banyak kendala, terutama pada penyelesaian soal-soal cerita. Hal ini terlihat dari hasil belajar yang diperoleh mahasiswa masih tergolong rendah. Dari hasil pengamatan diperoleh bahwa mahasiswa kurang aktif dalam proses pembelajaran, misalnya kurang memperhatikan ketika dosen menjelaskan, kesulitan dalam menyelesaikan soal, kurang aktif bertanya dan menjawab pertanyaan.

Pembelajaran dalam perkuliahan Statistika Matematika I memerlukan penelaahan yang mendalam serta banyak soal-soal cerita yang berkaitan dengan kehidupan sehari-hari. Dalam perkuliahan ini banyak contoh- 
contoh realistik, namun mahasiswa masih kesulitan menelaahnya untuk diselesaikan dalam bentuk konsep-konsep matematika Oleh karena itu maka dilakukan penelitian untuk mengembangkan model pembelajaran kooperatif menggunakan pendekatan realistik pada mata kuliah Statistika Matematika I. Menurut Hudoyo (1988) ketika seseorang belajar matematika terjadi proses berpikir, sebab seseorang dikatakan berpikir jika orang tesebut melakkan kegiatan mental. Seseorang akan merasa mudah memecahkan masalah dengan bantuan matematika, karena ilmu matematika memberikan kebenaran berdasarkan alasan logis dan sistematis.

Dalam pembelajaran matematika konsep yang sangat penting apabila kurang ditekankan sangat mempengaruhi konsep yang akan dipelajari. Oleh karena itu pemahaman tentang matematika sangat diperlukan dalam belajar. Dalam mempelajari matematika perlu bekerjasama agar terjadi difusi pengetahuan dari yang berkemampuan tinggi kepada siswa yang berkemampuan rendah agar terjadi pemhaman yang merata. Salah satu alternatifnya adalah melalui pembelajaran kooperatif.

Pembelajaran kooperatif menurun Thelen dalam Arends (1989) lebih mengedepankan pada dinamika kelompok serta secara pedagogi mengedepankan pada struktur kelompok. Arends (1989) mengemukakan bahwa setidaknya terdapat 3 tujuan utama dalam pembelajaran kooperatif yaitu 1) peningkatan prestasi akademik, 2) hubungan sosial, dan 3) ketrampilan bekerjasama dalam memecahkan masalah. Budijastuti (2002) menyatakan bahwa ada peningkatan hasil belajar biologi melalui pembelajaran kooperatif pada mahasiswa program studi fisika.

Model pembelajaran kooperatif tipe STAD dimaksudkan untuk memotivasi siswa dalam menguasai materi pelajaran yang disajikan oleh guru. Jika suatu kelompok ingin memperoleh penghargaan kelompok maka setiap anggota kelompok harus dapat saling membantu teman satu kelompoknya. Setiap anggota menampilkan kinerja terbaiknya (aspek akuntabilitas individu), sehingga dapat memperoleh nilai kuis yang maksimal. Karena nilai kelompok bergantung pada perkembangan individu, maka setiap anggota memiliki kesempatan untuk berhasil yang sama (Sidharta 2004). Menurut Slavin (1995) langkah STAD terdiri dari 1) Penyajian Kelas 2) belajar dalam kelompok 3) Tes/ kuis 4) Skor peningkatan individu dan 5) Pengakuan kelompok, sedangkan Ibrahim, 2000 menyebutkan: 1) persiapan awal, 2) penyajian materi pelajaran, 3) kegiatan kelompok, 4) evaluasi, 5) 
penghargaan kelompok dan perhitungan skor awal dan pengubahan kelompok.

Menurut Widyantini (2008)

Langkah-langkah

penerapan pembelajaran kooperatif tipe STAD adalah:

a. Guru menyampaikan materi pembelajaran kepada siswa $b$. Guru memberikan tes/kuis kepada setiap siswa secara individu c. Guru membentuk beberapa kelompok. Setiap kelompok terdiri dari 4 - 5 anggota, dimana anggota kelompok mempunyai kemampuanakademik yang berbeda-beda (tinggi, sedang, dan rendah). d. Guru memberikan tugas kepada kelompok berkaitan dengan materi yang telah diberikan, mendiskusikannya secara bersama-sama, saling membantu antaranggota lain, dan memastikan bahwa setiap kelompok dapat menguasai materi. e. Guru memberikan tes/kuis kepada setiap siswa secara individu. f. Guru memfasilitasi siswa dalam membuat rangkuman,pada materi pembelajaran yang telah dipelajari. g. Guru memberi penghargaan kepada kelompok berdasarkan perolehan nilai peningkatan hasil belajar individual dari nilai awal ke nilai kuis berikutnya.

Matematika sebagai aktivitas manusia berarti bahwa manusia harus diberikan kesempatan untuk menemukan kembali ide dan konsep matematika dengan bimbingan orang dewasa
(Gravemeijer, 1994 dalam Soejadi, 2001). Upaya ini dilakukan melalui penjelajahan berbagai situasi dan masalah-masalah realistik. Realistik dalam hal ini dimaksudkan tidak hanya menyatu pada realitas tetapi pada sesuatu yang dapat dibayangkan oleh siswa (Slettenhaar, 2000). Materi pembelajaran matematika meliputi: 1) fakta, 2) konsep (pengertian, 3) ketrampilan penalaran, 4) ketrampilan algoritmik, 5) ketrampilan menyelesaikan masalah (problem solving), dan 6) ketrampilan melakukan penyelidikan (investigation).

Matematika

realistik menurut Soedjadi (2001) memiliki filsafat dasar yaitu bahwa "matematika adalah aktivitas manusia" dan tidak lagi :dipandang "siap pakai”. Filsafat ini mengakibatkan perubahan yang mendasar tentang proses pembelajaran matematika. Tidak lagi hanya pemberian informasi dalam pembelajaran matematika, tetapi harus mengubah menjadi aktivitas manusia untuk memperoleh pengetahuan matematika. Pendekatan matematika realistik memiliki prinsip 1) Reinvention dan Progressive matematization, 2) Didactical phenomenology dan 3) Self Developed Model. Sedangkan karakteristiknya meliputi: 1) Menggunakan konteks, 2) Menggunakan model, 3) Menggunakan kontribusi siswa, 4) 
Interaksi, dan 5) Interwining. Penelitian Kultsum (2009) menunjukkan adanya peningkatan pemahaman dan respon positif pada mata pelajaran matematika menggunakan pendekatan realistic. Kania (2006) menyatakan dari hasil penelitiannya bahwa ada peningkatan kemampuan penalaran dan komunikasi matematika.

\section{METODE PENELITIAN}

$\begin{array}{ccr}\text { Penelitian } & \text { ini adalah } \\ \text { penelitian } & \text { pengembangan }\end{array}$ (Reseach and Development $/ R \&$ $D)$. Penelitian ini dilakukan pada mahasiswa program studi Pendidikan Matematika Universitas Muhammadiyah Metro, Lampung. Pada penelitian ini akan didapatkan suatu pengembangan model pembelajaran kooperatif menggunakan pendekatan realistik, yang dijabarkan dalam bentuk gambaran dan kendala proses pembelajaran menggunakan model pembelajaran kooperatif, gambaran dan kendala proses pembelajaran menggunakan realistik dan peningkatan aktivitas dan hasil belajar menggunakan model pembelajaran kooperatif menggunakan pendekatan realistik. Data yang digunakan dalam penelitian ini adalah data kualitatif dan kuantitatif. Tahaptahap dalam penelitian ini adalah: Studi Pendahuluan, Perencanaan, Pengembangan

dan validasi/evaluasi (Borg \& Gall, 1996).

Tahap Studi pendahuluan dilakukan dengan melaksanakan perkuliahan statistika matematika I menggunakan pembelajaran kooperatif dan perkuliahan menggunakan pendekatan realistik untuk mengetahui gambaran dan kendala pelaksanaan pembelajaran. Pengambilan data dilakukan melalui wawancara, catatan lapangan dan angket yang dilakukan oleh observer Hasilnya diperoleh gambaran dan kendala pelaksanaan pembelajaran dalam kegiatan kooperatif dan langkah realistiknya.

Pada tahap perencanaan yaitu merencanakan pembuatan produk melalui proses: 1) Melakukan analisis kebutuhan dan Tujuan Umum, 2) Analisis instruksional dan karakteristik mahasiswa, 3) Menuliskan tujuan pembelajaran khusus. (Dick, Carey \& Carey 2009). Pada tahap ini membuat instrumen analisis kebutuhan (wawancara untuk dosen dan mahasiswa) untuk mengembangkan model pembelajaran kooperatif menggunakan pendekatan realistik.

Pada tahap pemngembangan meliputi: 4) Membuat alat penilaian 5) Mengembangkant strategi pembelajaran dan 6) Mengembangkan bahan ajar terhadap desain model pembelajaran kooperatif menggunakan pendekatan 
realistik. (Dick, Carey \& Carey 2009). Instrumen yang digunakan adalah tes dan kisi-kisinya berdasarkan tujuan pembelajaran. Selanjutnya mengembangkan model pembelajaran dalam bentuk sintaks pembelajaran dan Rencana Pelaksanaan Pembelajaran (RPP), kemudian dikembangkan bahan ajarnya.

Produk yang dihasilkan dievaluasi (tahap validasi) melalui ujicoba skala terbatas, validasi ahli dan uji lapangan. Data diperoleh melalui wawancara, angket dan penilaian terhadap produk, dengan meminta pendapat dan review dari para ahli sesuai dengan bidangnya, baik mengenai pengembangan model pembelajaran maupun bahan ajar model pembelajaran kooperatif menggunakan pendekatan realistik. Sedangkan uji lapangan menggunakan proses penelitian tindakan kelas, yaitu pembelajaran bersiklus (2 siklus), masing-masing siklus meliputi tahapan perencanaan, pelaksanaan tindakan, monitoring, observasi dan refleksi (Mc. Kernan dalam Depdikbud, 1999). Dari validasi tersebut diperoleh review untuk merevisi model pembelajaran, analisis data pelaksanaan pembelajaran dan memperoleh kesimpulan.

\section{HASIL PENELITIAN DAN PEMBAHASAN}

Hasil

pembelajaran

kooperatif diperoleh data bahwa metode yang digunakan adalah: ceramah, pemberian tugas dan diskusi kelompok. Mahasiswa sebagian besar terlihat aktif dalam kegiatan diskusi kelompok. Karena ditekankan semua harus menguasai materi mereka banyak berperan dalam diskusi, walaupun beberapa ada yang tidak aktif berdiskusi. Media yang digunakan adalah LCD dan papan tulis, Rencana pelaksanaan pembelajaran (RPP) menggunakan model STAD dan bahan ajar tidak direncanakan dari awal. Gambaran respon mahasiswa sebesar $74,7 \%$. Kendala dalam pembelajaran antara lain: penyelesaian soal menggunakan penerapan rumus dan kurang menggunakan langkah realistik.

Pada pembelajaran realistik diperoleh gambaran bahwa metode yang digunakan adalah: ceramah, dan pemberian tugas. Soal-soal yang diberikan banyak berupa soal-soal yang real yang berkaitan dengan kehidupan sehari-hari, sehingga dalam penyelesaian tidak hanya menggunakan rumus-rumus tetapi juga menggunakan percobaan dengan masalah real Media yang digunakan adalah LCD dan papan tulis, Rencana pelaksanaan pembelajaran (RPP) menggunakan pendekatan realistik dan bahan ajar tidak direncanakan dari awal. Sedangkan gambaran respon mahasiswa sebesar $67 \%$. Kendalanya adalah beberapa mahasiswa yang mengalami kesulitan tidak menyelesaikan 
tugasnya karena mereka hanya bekerja mandiri dan tidak bertanya/berdiskusi dengan teman.

Berdasarkan hasil studi pendahuluan diperoleh gambaran bahwa dalam merencanakan pembelajaran dan bahan ajar tidak dipersiapkan dari awal dan langkah-langkah pembelajarannya tidak dibuat secara rinci. Mahasiswa mengalami kesulitan dalam menyelesaikan masalahmasalah realistik dikarenakan sebagian belum dapat menggunakan model matematika berdasarkan konteks dan mencari alternative pemecahan masalah. Oleh karena itu perlu didesain pembelajaran menggunakan model kooperatif dengan pendekatan realistic. Langkah-langkah pembelajarannya disajikan pada tabel 1.

Pada tahap perencanaan dilakukan untuk mengembangkan produk yaitu melalui analisis kebutuhan dilakukan dengan membuat pedoman wawancara dan pengamatan terhadap mahasiswa dan dosen. Berdasarkan hasil pengamatan dan wawancara dengan beberapa mahasiswa, mereka masih banyak yang belum menguasai mata kuliah Statistika Matematika I. Dari wawancara mereka kesulitan dalam beberapa masalah bagaimana menyelesaikan soal-soal permutasi, kombinasi dan menentukan peluang menyelesaikan soal yang berhubungan dengan kehidupan sehari-hari/ realistik dan mengalami kesulitan dalam memahami soal-soal yang memerlukan pemecahan masalah dengan alternatif yang tepat.

Berdasarkan analisis kebutuhan maka dikembangkan model pembelajaran kooperatif dengan pendekatan realistik, tujuan Instruksional umum dan khusus yaitu apa yang harus dikuasai mahasiswa setelah belajar. Pada tahap pengembangan dikembangkan instrumen penilaian berupa tes dan kisis-kisinya. Selanjutnya dikembangkan strategi pembelajaran yaitu Sintak/langkah pembelajaran yang merupakan gabungan dari model pembelajaran kooperatif dengan pendekatan realistik. Langkah pembelajaran kooperatif tipe STAD adalah: 1) persiapan awal, 2) penyajian materi pelajaran, 3) kegiatan kelompok, 4) evaluasi, 5) penghargaan kelompok dan perhitungan skor awal dan pengubahan kelompok (Ibrahim, 2000). Sedangkan dalam pembelajaran realistik karakteristiknya meliputi: 1) Menggunakan konteks, 2) Menggunakan model, 3) Menggunakan kontribusi siswa, 4) Interaksi, dan 5) Interwining. (Soedjadi 2001).

Sintaks dikembangkan dalam bentuk Rencana Pelaksanaan pembelajaran (RPP) menggunakan tahap urutan pembelajaran, metode, media dan waktu (Suparman 2012). Selanjutnya 
dikembangkan draft bahan ajar dengan materi pokok Dasar-dasar Kombinatorik dan Teori Peluang. RPP dan bahan ajar divalidasi oleh Expert Judgement yaitu 2 orang ahli pendidikan matematika (ahli materi) dan 2 orang ahli desain pembelajaran. Dari review ahli direkomendasikan bahwa rancangan pembelajaran layak digunakan dalam pembelajaran dengan skor rata-rata 4 (skala Likert) dan bernilai baik. Urutan langkah pembelajaran disajikan pada Tabel 1, susunan Rancangan Pelaksanaan pembelajaran dan bahan ajar disajikan pada Tabel 2 dan Tabel 3.

Tabel 1. Urutan Langkah Model Pembelajaran Kooperatif Menggunakan Pendekatan Realistik

\begin{tabular}{|c|l|}
\hline No & \multicolumn{1}{c|}{ Langkah-langkah Pembelajaran } \\
\hline 1 & Menjelaskan Materi perkuliahan \\
\hline 2 & $\begin{array}{l}\text { Memberikan masalah-masalah menggunakan pendekatan realistik yang meliputi tiga } \\
\text { fase yaitu: } \\
\text { a. Fase pengenalan: dosen memperkenalkan masalah realistik (menggunakan konteks) } \\
\text { b. Fase eksplorasi, mahasiswa dianjurkan bekerja dalam kelompok kecil terdiri dari 4- } \\
5 \text { orang. Membuat model situasi masalah, dan mendiskusikan pola. } \\
\text { c. Fase meringkas, mencari alternatif pemecahan masalah, membuat } \\
\text { kesimpulan/menyajikan hasil dan semua anggota harus memahami materi. }\end{array}$ \\
\hline 3 & $\begin{array}{l}\text { Memberikan tes untuk dikerjakan secara individu dan masing-masing mahasiswa tidak } \\
\text { diijinkan untuk saling membantu. }\end{array}$ \\
\hline 4 & Memberi penghargaan kepada kelompok yang memenuhi kriteria \\
\hline
\end{tabular}

Tabel 2. Susunan RPP pada mata kuliah Statistika Matematika I

\begin{tabular}{|l|l|l|l|c|}
\hline $\begin{array}{c}\text { URUTAN } \\
\text { KEGIATAN } \\
\begin{array}{c}\text { PEMBELAJA } \\
\text { RAN }\end{array}\end{array}$ & \multicolumn{1}{|c|}{ GARIS BESAR ISI } & METODE & $\begin{array}{c}\text { MEDIA } \\
\text { \& ALAT }\end{array}$ & $\begin{array}{c}\text { WAKTU } \\
\text { (MENIT) }\end{array}$ \\
\hline \multicolumn{1}{|c|}{2} & 3 & 4 & 5 \\
\hline $\begin{array}{l}\text { I. TAHAP PENDAHULUAN } \\
\text { Seskripsi } \\
\text { singkat }\end{array}$ & $\begin{array}{l}\text { Pentingnya materi perkuliahan } \\
\text { yang akan diajarkan yaitu Statistika } \\
\text { Matematika yang memuat dasar- } \\
\text { dasar kombinatorik dan konsep } \\
\text { peluang serta penggunaannya } \\
\text { dalam matematika dan bidang lain }\end{array}$ & $\begin{array}{l}\text { Ceramah/ } \\
\text { Ekspositori }\end{array}$ & $\begin{array}{l}\text { LCD \& } \\
\text { laptop }\end{array}$ & 8 menit \\
\hline $\begin{array}{l}\text { Relevansi dan } \\
\text { manfaat }\end{array}$ & $\begin{array}{l}\text { Menjelaskan relevansi pada } \\
\text { kehidupan sehari-hari atau pada } \\
\text { bidang kajian lain, }\end{array}$ & Ceramah & $\begin{array}{l}\text { LCD \& } \\
\text { Laptop }\end{array}$ & 7 menit \\
\hline $\begin{array}{l}\text { Tujuan } \\
\text { Instruksional } \\
\text { Khusus }\end{array}$ & $\begin{array}{l}\text { 1)Menyelesaikan Soal perkalian } \\
\text { dan penjumlahan dalam Teori } \\
\text { Kombinatorik, 2) Menggunakan } \\
\text { prinsip okupansi (penempatan) } \\
\text { dalam menyelesaikan soal }\end{array}$ & Ceramah & $\begin{array}{l}\text { LCD \& } \\
\text { laptop }\end{array}$ & 5 menit \\
\hline
\end{tabular}




\begin{tabular}{|c|c|c|c|c|}
\hline \multicolumn{5}{|c|}{ II. TAHAP PENYAJIAN } \\
\hline Uraian & $\begin{array}{l}\text { Menjelaskan tentang teori } \\
\text { kombinatorik dengan prinsip } \\
\text { perkalian dan penjumlahan dan } \\
\text { prinsip okupansi (penempatan) }\end{array}$ & $\begin{array}{l}\text { Ceramah } \\
\text { dan Tanya } \\
\text { jawab }\end{array}$ & $\begin{array}{l}\text { LCD, } \\
\text { whiteboa } \\
\text { rd }\end{array}$ & 20 menit \\
\hline Contoh & $\begin{array}{l}\text { Memberikan contoh-contoh } \\
\text { penjumlahan dan perkalian dalam } \\
\text { teori kombinatorik dan prinsip } \\
\text { okupansi dalam bentuk masalah } \\
\text { real. }\end{array}$ & $\begin{array}{l}\text { Ceramah } \\
\& \text { Tanya } \\
\text { jawab }\end{array}$ & $\begin{array}{l}\text { LCD, } \\
\text { Laptop \& } \\
\text { whiteboa } \\
\text { rd }\end{array}$ & 20 menit \\
\hline Latihan & $\begin{array}{l}\text { Dosen memberikan masalah- } \\
\text { masalah menggunakan pendekatan } \\
\text { realistik yang meliputi tiga fase } \\
\text { yaitu: 1) Fase pengenalan: dosen } \\
\text { memperkenalkan masalah realistik } \\
\text { (menggunakan konteks), 2) Fase } \\
\text { eksplorasi, mahasiswa dianjurkan } \\
\text { bekerja dalam kelompok kecil } \\
\text { terdiri dari 4-5 orang. Membuat } \\
\text { model situasi masalah, } \\
\text { mendiskusikan pola yang dibentuk. } \\
\text { 3) Fase meringkas, mencari } \\
\text { alternatif pemecahan masalah, } \\
\text { membuat kesimpulan/menyajikan } \\
\text { hasil dan semua anggota harus } \\
\text { memahami materi tersebut.. }\end{array}$ & $\begin{array}{l}\text { Model } \\
\text { Kooperatif } \\
\text { STAD } \\
\text { dengan } \\
\text { pendekatan } \\
\text { realistik }\end{array}$ & $\begin{array}{l}\text { LCD, } \\
\text { Laptop \& } \\
\text { whiteboa } \\
\text { rd }\end{array}$ & 40 menit \\
\hline
\end{tabular}

\section{TAHAP PENUTUP}

\begin{tabular}{|l|l|l|l|l|}
\hline $\begin{array}{l}\text { Pemberian tes } \\
\text { dan umpan } \\
\text { balik }\end{array}$ & $\begin{array}{l}\text { Memberikan tes untuk } \\
\text { dikerjakan secara individu dan } \\
\text { masing-masing mahasiswa } \\
\text { tidak diijinkan untuk saling } \\
\text { membantu. } \\
\text { Memberi penghargaan kepada } \\
\text { kelompok yang memenuhi } \\
\text { kriteria }\end{array}$ & $\begin{array}{l}\text { Model } \\
\text { STAD } \\
\text { dengan } \\
\text { pendekatan } \\
\text { realistik. }\end{array}$ & $\begin{array}{l}\text { Lembar } \\
\text { tes, LCD } \\
\text { \& labtop }\end{array}$ & $\begin{array}{l}20 \\
\text { menit }\end{array}$ \\
\hline Tindak Lanjut & $\begin{array}{l}\text { Menjelaskan kembali bagian-bagian } \\
\text { yang belum dipahami oleh } \\
\text { mahasiswa. }\end{array}$ & Ceramah & $\begin{array}{l}\text { LCD, } \\
\text { Lembar } \\
\text { kerja }\end{array}$ & 10 menit \\
\hline Jumlah & & & $150 \mathrm{mnt}$ \\
\hline
\end{tabular}

Tabel 3. Susunan Materi Bahan Ajar Statistika Matematika I

\begin{tabular}{|c|l|l|}
\hline Bab & \multicolumn{1}{|c|}{ Materi Pokok } & \multicolumn{1}{c|}{ Sub Materi Pokok } \\
\hline I & Dasar-dasar & A. Peran Statistika dan peluang \\
& Kombinatorik & $\begin{array}{l}\text { B. Teori Kombinatorik } \\
\text { C. Permutasi dan kombinasi }\end{array}$ \\
\hline II & Teori peluang & $\begin{array}{l}\text { A. Pendahuluan } \\
\text { B. Percobaan, ruang sampel dan kejadian } \\
\end{array}$ \\
& & C. Peluang Kejadian dan penafsirannya \\
\hline
\end{tabular}

\section{$8 \mid$ Aksioma}

Jurnal Pendidikan Matematika FKIP Univ. Muhammadiyah Metro 


\begin{tabular}{|c|c|c|}
\hline & & $\begin{array}{l}\text { D. Peluang komplemen suatu kejadian } \\
\text { E. Peluang kejadian saling bebas saling lepas dan } \\
\text { bersyarat } \\
\text { F. Percobaan Bernoulli } \\
\text { G. Menghitung ruang sampel dan kejadian } \\
\text { H. Aksioma dan sifat peluang }\end{array}$ \\
\hline III. & Distribusi Peluang & $\begin{array}{l}\text { A. Distribusi Binomial } \\
\text { B. Distribusi Geometrik } \\
\text { C. Poisson } \\
\text { D. Exponensial }\end{array}$ \\
\hline
\end{tabular}

RPP dan bahan ajar tersebut diuji di lapangan dalam bentuk penelitian tindakan kelas yang dilaksanakan dalam 2 siklus. Tahapan setiap siklus adalah perencanaan, pelaksanaan tindakan evaluasi refleksi. Observasi dilakukan untuk mengetahui aktivitas realistik dan proses kooperatif, angket untuk menilai respons mahasiswa, tes untuk menilai hasil belajar sedangkan catatan lapangan untuk melihat kendala dan proses pembelajaran. Hasil observasi dan catatan lapangan dapat dilihat pada Tabel 4.

Tabel 4. Ringkasan Hasil observasi aktivitas pada Perkuliahan Statistika Matematika

\begin{tabular}{|c|c|c|c|}
\hline \multicolumn{4}{|c|}{1} \\
\hline Aspek aktivitas & Siklus I & Siklus & Peningkatan \\
\hline $\begin{array}{l}\text { 1) Aktivitas dalam memperhatikan } \\
\text { pembelajaran }\end{array}$ & 98 & 99,3 & 1,3 \\
\hline 2) Aktivitas menggunakan konteks & 92,7 & 97,3 & 4,4 \\
\hline 3) Aktivitas menggunakan model & 92 & 98 & 6 \\
\hline $\begin{array}{l}\text { 4) Aktivitas berdiskusi dalam } \\
\text { kelompok }\end{array}$ & 97,3 & 99,3 & 2 \\
\hline $\begin{array}{l}\text { 5) Aktivitas mencari alternatif } \\
\text { pemecahan masalah }\end{array}$ & 93,3 & 96,7 & 3.4 \\
\hline 6) Menyimpulkan/ menyajikan hasil & 95,3 & 97,7 & 2,4 \\
\hline Rerata & 94 & 98,1 & 4,1 \\
\hline
\end{tabular}

Berdasarkan hasil di atas maka diperoleh temuan bahwa: 1) Ada peningkatan aktivitas mahasiswa sebesar $4,1 \%$, dengan peningkatan aktivitas yang paling tinggi adalah: menggunakan model $(6 \%)$ dan menggunakan konteks (4\%), sedangkan peningkatan yang paling rendah adalah memperhatikan pembelajaran $(1,3 \%)$ dan berdiskusi dalam kelompok (2\%), namun aspek ini aktivitasnya sudah tinggi.. 2) Respon mahasiswa sebesar $67 \%$ (pra siklus) menjadi 79,7\% (siklus II) sehingga meningkat sebesar 11,7\% 3) Hasil belajar mahasiswa sebesar 71,6 pada siklus I dan 
sebesar 77,7 pada siklus II, sehingga meningkat sebesar $6,1,4$ ) Pelaksanaan pembelajaran berjalan dengan baik melalui pendekatan realistic (menggunakan konteks, model, alternatif pemecahan masalah dan menyimpulkan). 5) Pada fase menggunakan model matematika dan pemecahan masalah sangat tepat menggunakan belajar kooperatif, 6) Mahasiswa dapat membedakan permutasi dan kombinasi, 7) Mahasiswa dapat membedakan kejadian saling bebas, saling lepas dan kejadian bersyarat, 8)Kendala dalam pembelajaran kooperatif menggunakan pendekatan realistic waktu yang diperlukan lebih lama dibandingkan dengan pembelajaran biasa.

\section{KESIMPULAN DAN SARAN}

Model
kooperatif membelajaran
pendekatan realistik adalah model
pembelajaran yang menggunakan
langkah-langkah realistik dengan
proses kooperatif. Langkah-
langkah pembelajarannya adalah:
1) Menjelaskan materi perkuliahan, 2) Memberikan masalah-masalah menggunakan pendekatan realistik yang meliputi tiga fase yaitu: a) Fase pengenalan: dosen memperkenalkan masalah realistik (menggunakan kontteks), b) Fase eksplorasi, mahasiswa dianjurkan bekerja dalam kelompok kecil terdiri dari 4-5 orang. membuat model situasi masalah, mendiskusikan pola yang dibentuk. c) Fase meringkas, mencari alternatif-alternatif pemecahan masalah, membuat kesimpulan/menyajikan hasil dan semua anggota harus memahami materi tersebut 3) Memberikan tes untuk dikerjakan secara individu dan masing-masing mahasiswa tidak diijinkan untuk saling membantu. 4) Memberi penghargaan kepada kelompok yang memenuhi kriteria.

Hasil uji lapangan diperoleh ada peningkatan aktivitas belajar respon mahasiswa dan hasil belajar mahasiswa dari setiap siklus. Pada konsep permutasi dan kombinasi dapat dipahami menggunakan konsep penjumlahan/ perkalian dan okupansi. Mahasiswa dapat membedakan permutasi dan kombinasi, serta perbedaan peluang kejadian bebas, saling lepas dan bersyarat berdasarkan langkah menggunakan konteks, menggunakan model dan pemilihan pemecahan masalah. Kendala dalam pembelajaran kooperatif menggunakan pendekatan realistik adalah waktu yang diperlukan lebih lama dibandingkan dengan pembelajaran biasa terutama pada langkah diskusi kelompok dan pemilihan alternatif pemecahan masalah. 


\section{DAFTAR PUSTAKA}

Arend, R. 1989. Learning to Teach. New York. Mc. Graw Hill

Borg dan Gall. 1996. Educational Research, Sixth Edition, New York, Pearson Education

Budijastuti, W, 2002. Pembelajaran Kooperatif TOT, Jakarta.

Depdikbud. 1999. Penelitian Tindakan Action Reseach. Jakarta Depdikbud Ditjen Dikdasmen, Direktorat Pendidikan Umum.

Dick, W. Carey, L. and Carey, J.O. 2009. The Systematic Design of Instruction Eighth Edition, New York, Alyin \& Bacon

Hudoyo, H. 1988. Mengajar Belajar Matematika. Jakarta, Depdikbud.

Ibrahim dkk, 2000. Pembelajaran Kooperatif. Surabaya, UNESA

Kania, F. 2006. Pembelajaran Matematika dengan Pendekatan Realistic Mathematics Education Sebagai Upaya Meningkatkan Kemampuan Penalaran dan Komunikasi Matematika Siswa SD
Sukajadi Bandung. Skripsi PGSD, Bandung UPI.

Kultsum, S.U. 2009. Penerapan pendekatan matematika Realistik.

Matematika.upi.edu/index.ph p/penerapan pendekatan matematika realistik. Diunduh tanggal 27 Juni 2012

Sidharta, A. 2004. Pembelajaran Kooperatif, Modul Diklat Berjenjang. Bandung, Depdiknas Ditjen Dikdasmen, Pusat pengembangan Penataran Guru IPA.

Slavin, R.E. 1995. Cooperative Learning Theory, Reseach and Practice. Boston: Allyn and Bacon.

Slettenhaar, 2000. Adapting Realistic Mathematics Education in the Indonesian Context" dalam Majalah Ilmiah Himpunan Matematika Indonesia (Proseding Konperensi nasional Matematika X ITB, 17-20 Juli 2000)

Soedjadi 2001. Pembelajaran Matematika berjiwa RME Suatu pemikiran Rintisan Ke arah Baru. Makalah Seminar Nasional "Pendidikan Matematika Realistik Indonesia" Tanggal 14-15 
e-ISSN 2442-5419 Vol. 5, No. 1 (2016) 1-12

November $2001 \quad$ di

Universitas Sanata Dharma, Yogyakarta.

Suparman, M.A. (2012). Desain

Instruksional Modern.

Jakarta, Erlangga

Widyantini, Th. 2008. Penerapan

Pendekatan Kooperatif

STAD dalam Pembelajaran

Matematika SMP.

p4tkmatematika.org/fasilitas/

21.pendekatan

kooperatifSTAD.pdf.

Diunduh tanggal 27 Juni

2012 